\title{
ASSESSING THE IMPACT OF TECHNOLOGY ADOPTION ON PRODUCTIVITY OF PLANTAIN FARMERS IN NIGERIA
}

\author{
Afodu, O.J*', Akinboye, O.E., Akintunde, A.O., Ndubuisi-Ogbonna, L.C., \\ Shobo, B.A., Oyewumi, O.S.
}

Department of Agriculture and Industrial Technology, Babcock University, Nigeria

*corresponding author: afoduo@babcock.edu.ng

\begin{abstract}
Sub-Saharan Africa has been plaque with food insecurity due to lack of adoption of modern technology to improve their productivity. Technology is the systematic application of scientific or other organized body of knowledge to practical purposes. This includes new ideas, inventions, innovations, techniques, methods and materials. Since increasing agricultural productivity is critical to meeting the continues rise in demand for food, agricultural technologies will play immense role in increasing the production of food. As a result, it is useful to examine the adoption of technologies among farmers. A multistage sampling technique was used for the selection of five hundred and fifty - six plantain farmers. The data were collected through the administration of a wellstructured questionnaire on a cross-section surveyed of plantain farmers. The result of the study shown that educating the plantain farmers in Nigeria will enable them adopt new technologies which will enhance their productivity.
\end{abstract}

Keywords: Adoption; Multistage; Plantain; Productivity; Technology

http://dx.doi.org/10.21776/ub.agrise.2021.021.4.8

Received 5 April 2021

Accepted 3 October 2021

Available online 31 October 2021

\section{INTRODUCTION}

Economic policies depend heavily on the agricultural sector in the Sub-Sahara Africa (SSA). According to the report of World Bank (2014), agricultural growth has led to Food security and income growth which creates spill over effects to the remaining sectors. The declining rate of African population living in poverty has dropped drastically from 50\% in 1981to 45\% in 2012, African Development Bank/AfDB, (2014), but in SubSaharan country's $48 \%$ of the populations were found to be food insecure.

Abraham, et al; (2014) suggested that boosting the agricultural sector can be a solution for reducing the abject food insecurity in the Sub-Sahara Africa. Some studies shows that production and productivity of the agricultural sector in SSA is low due to low technological adoption and techniques among others (Abraham et al., 2014; Berihun et al., 2014; Gashaw et al., 2014; Tsegaye and Bekele, 2012; Lulit et al., 2012; MoFED, 2012).

Akubuilo et al., (2007) defines adoption as a decision made by an individual or group to use an innovation in a continuous manner. They also went further to define technology as the systematic application of scientific or other organized body of knowledge to practical purposes.
Meeting the demand and supply gap of food in the SSA is depended on increase in agricultural productivity which can be achieved through the adoption of agricultural productivity. Agricultural technologies have been found to include all forms of improved techniques and practices which increases the growth of agricultural output (Jain, et al; 2009).

The finding of Loevinsohn,et al; (2013) shows that there are common areas of technology development and promotion for crops which include new varieties and management regimes; soil as well as soil fertility management; weed and pest management; irrigation and water management.

Food and Agricultural Organisation (FAO, 2011) reported that Nigeria is one of the largest plantain producers in West Africa with an annual output of about 2.74 million metric tons. In Nigeria, plantain is one of the major foods containing about $35-40 \%$ of carbohydrate. Plantain has been found to be left in the hands of subsistence farmers who account for about 80 percent of Nigerian agricultural output.

Plantain (Musa paradisiaca) belong to the family Musaceae which is a common horticultural crop cultivated in Nigeria, and its production requires an optimum temperature of $300 \mathrm{C}$, mean 
monthly rainfall of $100 \mathrm{~mm}$, soil $\mathrm{pH}$ of $4.5-7.5$ and a partly drained sandy-loam soil (Ajiboye, 2016)

The report of IITA (2009) shows that plantain is among the primary sources of carbohydrates in humid tropical Africa as it contains about $35 \%$ carbohydrate, 0.2 to $0.5 \%$ fats, $1.2 \%$ protein, and $0.8 \%$ ash. This repot implies that plantain can serve as source of food for the plantain farming households. According to the study of Adejoro et al., (2010) noted that plantains if properly cultivated have the potential to contribute to reduce food insecurity and also minimized rural poverty. In the world ranking of crops, plantain has been ranked fourth after rice, wheat, and maize, as the most important food crop in the world (IITA, 2014). plantain is an important staple food crop for both rural and urban areas and occupies a strategic position for rapid food production in Nigeria.

This study thereby assessed how the impact of technology adoption by plantain farmers can improve their productivity and profitability thereby reducing the food insecurity of the farmers.

\section{MATERIALS AND METHODS}

This study was conducted out in the southwest region of Nigeria which consists of Lagos, Ogun, Oyo, Osun, Ondo and Ekiti States. The area lies between longitudes 20311 and 60 001East and latitudes 60211 and $80371 \mathrm{~N}$, with a total land area of about $77,818 \mathrm{~km} 2$. It is bounded in the east by Edo and Delta State in the north by Kwara and Kogi States, in the west by the Republic of Benin and in the south by the Gulf of Guinea. The climate of Southwest Nigeria is tropical in nature and is characterized by wet and dry seasons. The mean temperature ranges between $210 \mathrm{C}$ and $340 \mathrm{C}$, it has an annual rainfall range between $150 \mathrm{~mm}$ and $3000 \mathrm{~mm}$. The wet season is associated with the southwest monsoon wind from the Atlantic Ocean while the dry season is associated with the northeast trade wind from the Sahara-desert, Ojo,et al; (2019). Multistage sampling technique was used for the selection of the plantain farmers. The first stage involves purposive selection of three states (Ogun, Oyo and Osun), the second stage involves a purposive selection of two Agricultural Development Programme (ADP) zones from each of the state. The third stage was the purposive selection of two blocks per zone based on the concentration of plantain farmers. The fourth stage consist the random selection of five farming cells from each of the block making a total of sixty (60) farming cells. Lastly, ten plantain farmers were randomly selected from each farming cell giving a total sample size of 600 plantain farmers. The data were collected through the administration of a well-structured questionnaire on a cross-section surveyed of plantain farmers in the study area.

\section{METHOD OF DATA ANALYSIS}

Descriptive, adoption index and inferential statistics were adopted for analysing the data for the study. The descriptive statistical tools used were frequency and percentages. Adoption index was computed for technologies adopted, while Logit regression models was used to analysed the impact of technology adoption on the farmers' productivity.

\section{Estimation of the Adoption index}

Adoption index was used in capturing the various technologies adopted by the farmers in the study area, and it is specified in equation 1 following Mihiretu (2008), Ayalew (2011) and Obayelu et al., (2016), was used to measure the extent of technology adoption at the time of the survey for multiple practices, which shows to what extent the respondent has adopted the most set of technology.

$$
A l_{i}=\sum \frac{\left[\frac{A H_{i}}{A T_{i}}+\frac{S R A_{i}}{S R R}+\frac{F A_{i}}{F R}+---------N\right]}{N P}
$$

Where:

AI $i=$ Adoption index $\mathrm{i}$ of respondents (which ranges between 0 and 1 )

$A H=$ area under improved variety of plantain of the ith farmer.

$A T i=$ Total area allocated for plantain production (improved variety+ local, if any) of the ith farmer.

$S R A i=$ Suckers rate applied per unit of area in the production of improved variety of plantain of ith farmer.

$\mathrm{S} R R=$ Suckers rate recommended for application per unit of area.

$F A i=$ amount of fertilizer applied per unit of area in the cultivation of improved variety of plantain by ith farmer,

$F R i=$ Amount of fertilizer recommended for application per unit of area in the cultivation of improved variety of plantain

$N P=$ Number of practices .

Logit regression was adopted to analyse the impact of technology adoption on the farmers productivity.

The model is specified as

$$
\begin{aligned}
Y_{i}= & \gamma_{0}+\sum \gamma_{\mathrm{j}} \mathrm{x}_{\mathrm{j}}+\varepsilon_{\mathrm{j}} \ldots \ldots \ldots \ldots \ldots \ldots \ldots \ldots \ldots \ldots \ldots \ldots \ldots \ldots \ldots \ldots \ldots \ldots \ldots \\
Y= & \gamma_{0}+\gamma_{1} \text { age }+\gamma_{2} \mathrm{sex}+\gamma_{3} \text { hhs }+\gamma_{4} \text { edu }+\gamma_{5} \text { farsize }+ \\
& \gamma_{6} \text { coopmem }+\gamma_{7} \text { accesstocre }+\gamma_{8} \text { marital }+ \\
& \gamma_{9} \text { ext.visit }+\varepsilon_{i}
\end{aligned}
$$

\section{Where:}

$Y_{i}=$ Output (in tons)

Age $=$ Farmers age $[$ in years $]$

Sex $=[$ Male $=1$, Female $=0]$

Hhs = Household Size [ Number]

Numyrsedu = Educational Status [in years]

Farsize $=$ farm size $[$ hectare $]$ 
Coop Mem = Cooperative Membership [yes = 1, no $=0]$

Accredit $=$ Farmers' Access to credit $[$ Accessed $=$ 1 , otherwise $=0]$

Marstatus $=$ Marital status $[$ Married $=1$, single $=0]$ Extvisit $=$ Extension visit [Number of visit per year] $\varepsilon_{i}=$ Random term

\section{RESULTS AND DISCUSSIONS}

Table 1 shows the demographic characteristics of the respondents. The farmers from table 1 age of shows that most of the plantain farmers are vibrant and still in their active age, which is within the age range of 30 - 39 years had the highest (33.9) percent. This suggest that most of the respondents are likely to adopt most technologies used in plantain production this will translate to increase in their productivity. The study of Tang (2005) found that older workers are on average, less productive than younger workers and that labor force aging has a modest negative direct impact on productivity growth in Canada.

It was observed that the population of the respondents in the area of study were more of male with about 86.5 percent. This could be due to fact that agriculture has been viewed to be labor intensive and the female folks are mostly involving in the processing aspect of the venture rather than in the production aspect.

Table 1 shows that a large (52.9) percent of the farming households were between the ranges of 5 8 persons. This implies that there is likely to be enough man power to implement the available technologies.

Majority (40.5\%) of the respondents were found to be literate with a minimum of secondary school certification. It has been noticed in literature that education is succent in technology adoption.

A larger number $(46.6 \%)$ of the plantain farmers had plot size ranging from $4-6$ hectares of farm land. This implies that the farmers had enough space to adopt or try new technologies.

Being a member of farming cooperative has been linked to a higher rate of technology adoption. 73 percent of the plantain farmers in the study were found to belong at least a farming cooperative

Table 1 also shows that $52.9 \%$ of the farmers had access to credit facilities. The credit facilities will enable the farmers have access to new technologies in plantain production and hence increase their productivity.

Table 1

\begin{tabular}{|c|c|c|}
\hline Variable & Frequency & Percent \\
\hline Age & & \\
\hline $20-29$ & 38 & 6.8 \\
\hline $30-39$ & 189 & 33.9 \\
\hline $40-49$ & 146 & 26.3 \\
\hline $50-59$ & 144 & 25.9 \\
\hline 60 and above & 39 & 7.1 \\
\hline Total & 556 & 100.0 \\
\hline Sex & & \\
\hline Male & 481 & 86.5 \\
\hline Female & 75 & 13.5 \\
\hline Total & 556 & 100.0 \\
\hline Household Size (in Persons) & & \\
\hline $1-4$ & 113 & 20.3 \\
\hline $5-8$ & 294 & 52.9 \\
\hline 9 and above & 146 & 26.8 \\
\hline Total & 556 & 100.0 \\
\hline Education & & \\
\hline Non - Formal Education & 183 & 32.9 \\
\hline Primary & 112 & 20.1 \\
\hline Secondary & 225 & 40.5 \\
\hline Tertiary & 36 & 6.5 \\
\hline Total & 556 & 100.5 \\
\hline Farm Size & & \\
\hline $1-3$ & 184 & 33.1 \\
\hline $4-6$ & 256 & 46.5 \\
\hline 7 and above & 116 & 20.4 \\
\hline Total & 556 & 100.0 \\
\hline Cooperative & & \\
\hline YES & 406 & 73.0 \\
\hline NO & 150 & 27.0 \\
\hline Total & 556 & 100.0 \\
\hline
\end{tabular}




\begin{tabular}{|l|l|l|}
\hline Access to Credit & \\
YES & 294 & 52.9 \\
NO & 262 & 47.1 \\
Total & 556 & 100.0 \\
\hline
\end{tabular}

Source: Field survey, 2020

The age of the had significant coefficient but with negative signs for some of the technologies such as land clearing, land preparation, improved sucker, organic fertilizer and harvester adopted by the farmers except for the herbicides which had a positive sign. This result shows that age has an indirect relationship to the technologies with negative coefficients. This also implies that age can affect the productivity of farmers, owing that young farmers may tend to be more productive. This result is inline findings of Afodu et al; (2019) who observed that the older household heads were, less diversified in the sources of livelihood they pursue. This shows that the younger farmers the more chances of adopting modern technologies on plantain production thereby increases their productivity. Ugwoke et al. (2005) also found that age is a good index to improved productivity because farmers' productivity is deemed to decrease as they age.

The regression shows that the household size had a positive coefficient for land clearing, land preparation, herbicide, inorganic fertilizer and harvester. This shows that a larger household size may lead to more adoption of the modern technologies in plantain production which could translate into increased productivity of the plantain farmers. The finding is in line with the findings of Olumba, (2014) who found that the household size influences farming decision on management practices. Fasina (2005) and Nwachukwu (2008) also noticed that the larger household size had a direct relationship with the productivity of the farmers.

Education of the respondents was found to be significant with positive coefficient for all the technologies adopted by the farmers. This could be due to the importance of education that has been found by different researchers to be an important tool in improving the productivity of the farmers. According to the findings of Oduro-Ofori, et al; (2014), education has a positive effect on agricultural productivity. This finding is also in accordance with the result of John et, al; (2020) who found that an increase farmers level of education, will lead to increase in the adoption of production technologies and this will further better the farmers productivity.
The farm size of the farmers was found to be significant for all the available production technologies expect for pest scaring devices and sprayer technologies, and also organic fertilizer technology was found to be negatively significant. The implication of farm size being positive and significant on other production technology is that as the farm size increases there is tendency for the farmers to adopt those technologies.

The coefficient of cooperative was observed to be for land clearing, organic fertilizer and inorganic fertilizer. This implied that farmers in cooperative are likely to adopt these technologies.

Access to credit facilities was found to be significant in all the available plantain production technologies adopted by farmers. This is in line with the a priori expectation, because if the farmers can have access to credit facilities, there is a high level of probability that those farmers will adopt the latest technologies to improve their productivity and subsequently improve their income and livelihood. This result is in accordance with the result of Afodu et al; (2019), they found that access to credit facilities may lead to increase in livelihood diversification thereby increasing the sources of the farmers' income.

Farmer size was found to be significant in only the land clearing technology

Extension agent visit to farms was found to increase the adoption of all the technologies adopted by the farmers in the study area. 
Table: 2 Factors affecting the rate of adoption of some production technology

\begin{tabular}{|c|c|c|c|c|c|c|c|c|c|}
\hline & $\begin{array}{c}\text { land } \\
\text { clearing }\end{array}$ & $\begin{array}{c}\text { land } \\
\text { preparatio } \\
\mathrm{n}\end{array}$ & $\begin{array}{l}\text { improved } \\
\text { sucker }\end{array}$ & $\begin{array}{c}\text { herbicid } \\
\text { e }\end{array}$ & $\begin{array}{l}\text { organic } \\
\text { fertilizer }\end{array}$ & $\begin{array}{l}\text { inorganic } \\
\text { fertilizer }\end{array}$ & pesticides & $\begin{array}{c}\text { spraye } \\
\text { r }\end{array}$ & harvester \\
\hline Age & $-.018 *$ & $-.065^{* *}$ & $-.029 * *$ & $.042 * *$ & $-.033 * *$ & .361 & .019 & -.004 & $-.051 * *$ \\
\hline Sex & .02 & .026 & -.003 & -.301 & .009 & .018 & .022 & .063 & .092 \\
\hline Hhs & $.011 * * *$ & $.014 * *$ & -.052 & $.026 * *$ & -.094 & $.115^{*}$ & .061 & -.185 & $.031 * *$ \\
\hline Edu & $.031 * *$ & $.035 * *$ & $.029 * *$ & $.062 * *$ & $.0045 * * *$ & $.002 *$ & $.017 * * *$ & $\begin{array}{r}.025 * \\
*\end{array}$ & $.110 *$ \\
\hline Farm Size & $.040 *$ & .012 & $.036 * * *$ & $.041 *$ & $-.076 * * *$ & $.044 * *$ & $.080 * *$ & .019 & $.069 * *$ \\
\hline Coop & $.033 * * *$ & .013 & .018 & .083 & $.013 * *$ & $.072 * *$ & .051 & -.023 & .070 \\
\hline Accestocre & $.049 * *$ & $.080 *$ & $.056 * *$ & $.055 * *$ & $.010 *$ & $.033 * *$ & $.066 * *$ & $.024 *$ & $.043 * *$ \\
\hline Farmex & $.005^{*}$ & .062 & .030 & .035 & -.038 & -.009 & .011 & - & -.020 \\
\hline Ext. Visit & $.044 * *$ & $.071 * * *$ & $.003 * *$ & $.059 *$ & $.009 * *$ & $.008 * *$ & $.039 *$ & $\begin{array}{r}.017 \\
.098 \\
*\end{array}$ & $.031 * *$ \\
\hline Const. & $.757 * * *$ & $.193 * *$ & $.514 * *$ & $.110^{*}$ & $.333 *$ & $.307 * *$ & $.552 * *$ & $.701 *$ & $.612 * *$ \\
\hline
\end{tabular}

\section{CONCLUSION}

Plantain is one the major food crops with a high level of vitamin $\mathrm{K}$ and highly productive in Nigeria. Technology adoption in plantain production is critical to productivity, food security, poverty reduction and improved vitamins in the country. This study examined assessing the impact of technology adoption on productivity of plantain farmers in Nigeria. Educational status of the respondents was found to be a very important variable as it was significant with positive coefficient in all the technologies adopted by plantain farmers in Nigeria. It was also deduced from the study that access to credit will enable plantain farmers in Nigeria to acquire technologies that will enhance their productivity. Farm size was also a notable factor to the adoption of technologies by the plantain farmers in Nigeria.

Recommendations

The following are the recommendations from this study:

1. The government should enforce the Land Use Act to enable plantain farmers in Nigeria get access to land, so as to encourage more commercial plantain production.

2. Educating the plantain farmers on modern technologies in the production of the crop should be encouraged.

3. The plantain farming households should be encouraged and assisted by providing the necessary technologies needed for plantain production.

\section{REFERENCES}

Abraham B, Araya H, Berhe T, Edwards S, Gujja B, Khadka R, Sen D, Koma Y, Sharif A, Styger E, Uphoff N, Verma A (2014). The system of crop intensification: Reports from the field on improving agricultural production, food security, and resilience to climate change for multiple crops. Addis Ababa, Ethiopia. Available at http://www.agriculture and food security.com/content/3/1/4.

Adejoro, M.A, Odubanjo A.O., and Fagbola B.O. (2010). Research Focus on Banana and

Plantain (Musa spp.): Nigerian Perspectives. Acta Horticulturae 879. DOI: 10.17660/ActaHortic.2010.879.95 AfDB (2014). African Development Group. Tracking Africa $^{\text {ee }}$ P Progress in Figures

Afodu, O.J., Afolami, C. A., Akinboye, O. E., Ndubuisi-Ogbonna, L. C., Ayo-Bello, T. A., Shobo, B. A and Ogunnowo, D. M. 2019. Livelihood diversification and its determinants on rice farming households in Ogun State, Nigeria. African Journal of Agricultural Research, 14 (35): 2104 - 2111

Aina, O.S., S. Ajijola, M.T. Bappah, I. Ibrahim, and I.A. Musa. 2012. Economic analysis of plantain marketing in Odigbo local government area of Ondo State, Nigeria. Global Adv. Res. J. Agr. Sci. 1(5):104109.

Ajiboye G. A. and Olaniyan J. O (2016). Characteristics and suitability evaluation of the "white soils" of Etung local government area for oil palm and plantain production. Department of Soil Science and Land Management, College of plant Science and Crop Production, Federal University of Agriculture Abeokuta, Abeokuta, Ogun State Nigeria. Agrosearch 16(2): 25-40

Akubuilo, C. J. C., E. E. Umebali., Mgbada, D. S. Ugwu., W. E. Egwu and M.U. Awoke, (2007)

"Readings in Agricultural Economics and Extension", Computer Edge Publishers, Enugu.pp.45-89

Ayalew A.M. (2011). Factors Affecting Adoption of Improved Haricot Bean Varieties and Associated Agronomic Practices in Dale Woreda, SNNPRS. Unpublished M.Sc. 
Thesis submitted to the Department of Plant and Horticultural Sciences, College of Agriculture, Hawassa University, Hawassa, Ethiopia. Accesses online Jan. 10, 2016 https://cgspace.cgiar.org/bitstream/handle/105 68/10291/FinalThesis_AlemituMuluget

a. pdf? sequence $=1 \&$ isAllowed $=y$

Berihun KH, Bihon KA, Kibrom AW (2014). Adoption and impact of agricultural technologies on farm income: evidence from Southern Tigary, Northern Ethiopia. Int. J. Food Agric. Econ. 2(4):91106.

Challa, Merga (2013).Determining Factors and Impacts of Modern Agricultural Technology Adoption in West Wollega, Munich, GRIN Publishing $\mathrm{GmbH}$, book/280336/determiningfactors-and-impactsof- modern-agricultural-technology-adoption.

Food and Agriculture Organization FAOSTAT (2011): Plantain Production Quantity in Nigeria 1961- 2009. Food and Agriculture Organization of the United Nations. FAO Rome.

Gashaw T, Alan B, Nicholas M, Tanguy B (2014). The impact of the use of new technologies on farmers'wheat yield in Ethiopia. International Food Policy Research Institute (IFPRI). Washington, DC

International Institute for Tropical Agriculture (2009): Banana and Plantain Systems, R4D Fact Sheet.

International Institute of Tropical Agriculture (2014). A reference manual on Plantain Cultivation in West Africa.

Jain R. Arora A \& Raju S. (2009). A Novel Adoption Index of Selected Agricultural Technologies:Linkages with Infrastructure and Productivity: Agricultural Economics Research Review 22 ; pp 109-120

John, A., O., Afolake, A., C., Lawrence, B., O. (2020). Effect of Livelihood Diversification and Technology Adoption on Food Security Status of Rice Farming Households in Ogun State. Nigeria, Agricultural SocioEconomics Journal, 20(3), 233-244 DOI: http://dx.doi.org/10.21776/ub.agrise. 2020. 020.3.7

Loevinsohn, M., Sumberg, M., Diagne, A., and Whitfield, S. (2013), Under What Circumstances and Conditions Does Adoption of Technology Result in Increased Agricultural Productivity? A Systematic Review, IDS, Brighton.

Lulit M, Ermias E, Zelalem H (2012). Public investment in irrigation and training for an agriculture-led development: a CGE approach for Ethiopia. Addis Ababa, Ethiopia.

Mihiretu, T. A., (2008). Farmers Evaluation and Adoption of Improved Onion Production
Package in Fogera District, South Gondar, Ethiopia. Unpublished M.Sc. Thesis Presented to The School of Graduate Studies Haramaya University, Ethiopia. Accessed online Jan. 10, 2016

https://cgspace.cgiar.org/bitstream/handle/105 68/683/Thesis_AdgoFarmers.

pdf? sequence $=1 \&$ is Allowed $=y$

MoFED (2012). Ethiopia"s progress towards eradicating poverty: An interim report on poverty analysis study. Addis Ababa, Ethiopia.

Obayelu, A. E., Okuneye, P. A., Shittu, A. M., Afolami, C. A. and Dipeolu, A. O. (2016). 'Determinants and the Perceived Effects of Adoption of Selected Improved Food Crop Technologies by Smallholder Farmers along the Value Chain in Nigeria.' Journal of Agriculture and Environment for International Development. 110 (1):155 - 172

Oduro-Ofori E, Aboagye, A.P., and Acguaye N.A. (2014). Effect of Education on the Agricultural

Productivity of Farmers in the Offinso Municipality. International Journal of Development Research 4(9): 1951-1960.

Ojo, T.O., Baiyegunhi, L.S.J., and Salami, A.O. 2019. Impact of credit demand on the productivity of rice farmers in South West Nigeria J. Econ. Beh. Stud., 11 (1), pp. 166180

Olumba, C. C., Rahji, M. A. Y. (2014). An Analysis of the Determinants of the Adoption of Improved Plantain Technologies in Anambra State, Nigeria. Journal of Agriculture and Sustainability, 5(2), 232-245.

Tang, Jianmin, and Weimin Wang (2005) 'Product market competition, skill shortages and productivity: evidence from Canadian manufacturing firms,' Journal of Productivity Analysis 23, 317-39

Tsegaye M, Bekele H (2012). Impacts of Adoption of Improved Wheat Technologies on

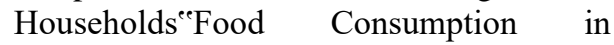
Southeastern Ethiopia. Selected Poster prepared for presentation at the International Association of Agricultural Economists (IAAE) Triennial Conference, Foz do Iguaçu, Brazil, 18-24 August, 2012.

Ugwoke, F.O., Adesope, O.M. \& Ibe, F.C. (2005). Youths participation in farming activities in rural areas of Imo State, Nigeria: implications for extension. J. Agricultural Extension, 8, 136-141.

World Bank Group (2014). Ethiopia poverty assessment. Document of the WB for official use only 